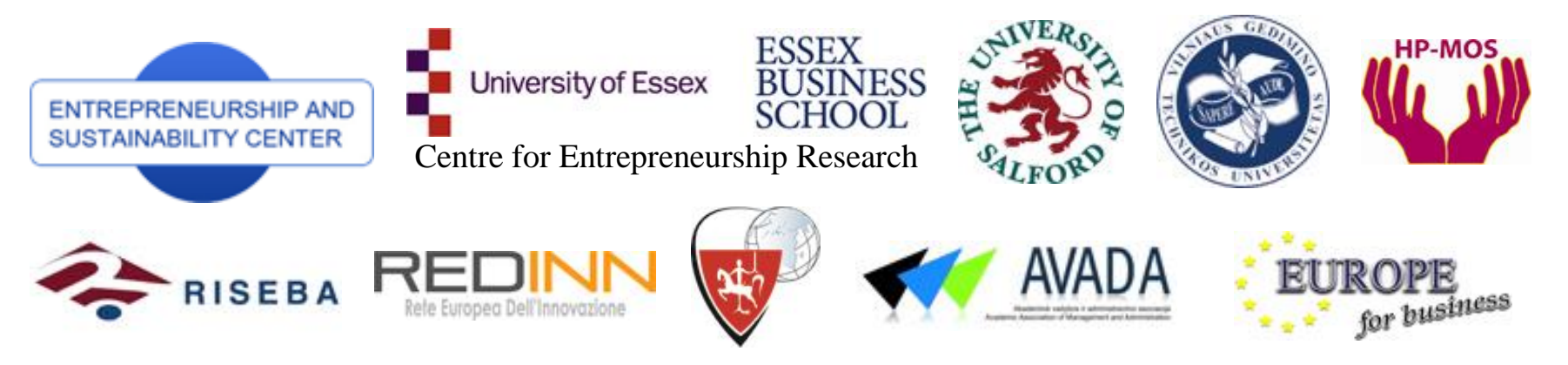

ENTREPRENEURSHIP AND SUSTAINABILITY ISSUES

ISSN 2345-0282 (online) http://jssidoi.org/jesi/aims-and-scope-of-research/ 2013 Volume 1(2): 116-123

http://dx.doi.org/10.9770/jesi.2013.1.2(6)

\title{
MOTIVATION TOOLS THOUGH LENSES OF PROSPECTIVE EMPLOYEES
}

\author{
Margarita Išoraitė \\ University of Applied Sciences, Business Management Faculty \\ Didlaukio str. 49, LT-08303 Vilnius, Lithuania \\ E-mail:misoraite@gmail.com
}

Received 3 October 2013; accepted 30 November 2013

\begin{abstract}
This article examines the theoretical aspects of employee motivation tools. A study conducted at V.A.Graičiūnas high management school. The results showed that most of respondents evaluated very good the physiological needs, the second - the security requirements, third place - the respect and esteem needs, the fourth - the needs of self-expression, in fifth place social needs. In terms of importance of motivating factors respondents evaluated wages and social security vacation time. Most respondents have got the monetary reward, a salary bonus, fixed bonuses for a job well done, insurance against accidents at work, professional phone and various benefits.
\end{abstract}

Keywords: Employees, motivation, employee motivation tools.

Reference to this paper should be made as follows: Išoraite, M., 2013. Motivation tools though lenses of prospective employees, Entrepreneurship and Sustainability Issues 1(2): 116-123.

http://dx.doi.org/10.9770/jesi.2013.1.2(6)

JEL Classifications: M12, M51, M54

\section{Introduction}

In today's world of human resources plays a large role in the organization. They are also called the blood of the organization. Human resource motivation literature deserves special attention. Many of motivation theories focus on review and evaluation. The motivation measures and their role in the organization were considered in many scientific papers of foreign and Lithuanian authors like Kim (2005), Kumpikaitè and Kalinauskienè (2011), Marcinkevičiūtè (2003, 2005, 2006), Musulaitė and Labžentienè (2008), Palidauskaitė and Segalovičienè (2008), Čerbatik (2010), Žaptorius (2007), Sakalas (2001), Atkinson and Feather (1974), Atkinson and Litwin (1960), Atkinson and Raynor (1978).

Research problem. The man with the ability and desire to work seen as the main driving force has declared a number of years. Therefore, the practical reasoning systems, their functioning and evaluation still requires a deeper study. This is especially true of the situation in Lithuania, where just last year realized that employee motivation is more than the promotional tools. Of course, it is wrong to say that so far that Lithuanian organizations or institutions motivation systems were not. They were, however, it is only a means of 
motivation (eg. wages, bonuses, leisure and so on.). But nevertheless, a practical systematic approach to the reasoning aspect of Lithuanian organizations or institutions is becoming increasingly important. In terms of motivation to work and work well, it comes to the abundance of factors stimulating work. This includes wages and salaries, and self-fulfillment, and respect, and self as belonging to a particular organization or team perception and career, and the creative atmosphere and bonuses, and management's confidence and ability to establish it. Motivating factors motivate different people differently. What is very important to the governor, is not necessarily as important and his subordinate, so to motivate your employees, employers should periodically talk with your employees and explain how employees satisfied with their work and what they are missing. Organization leaders must anticipate what will be their business, what, when and how they will have to implement the task. Performance and effects of the work of employees, so their competencies, attitudes, values determined by one or another of their behavior. Leaders must monitor employees' behavior and direct it to the organization in the right direction. The head has to pay to use their staff intellectual and spiritual potential. In the enterprises, where employers care about their employees, and strive to meet their needs and increase job satisfaction the motivation system has to be respectively elaborated. Employee motivation is realized depending on the organization and the needs of employees and the necessity, influenced by the environment. This requires the environmental and organizational needs analysis and, especially important to find out the individual needs of employees, because in order to motivate people to be aware of their properties, which in turn leads to their needs. The article aims - to assess employee motivation tools to their needs and abilities. To achieve this set the following tasks:

- To analyze the theoretical aspects of employee motivation;

- Investigate the respondents' views on employee motivation tools to their needs and abilities.

The paper used in the scientific literature analysis, questionnaire methods.

\section{Employee's motivation theoretical aspects}

Greenberg and Baron (2003) state, that motivation is set of the process that arouse, direct and maintain, as it is more realistic and simple as its consider the individual and his performance. Helepota (2005) defines motivation as person active participation and commitment to archieve the prescribed results. Education Development Center (2012) argues that employment skills can be defined as a planned activity through the work-related contexts are educated work-related skills: analyze and think critically, solve problems, communicate successfully, to achieve the result, to be able to learn to set priorities and stay organized, resist stress, to work with others, to take a leadership role. The financial crisis made all predictions cmplex; hence now it is extremely difficult to predict the future of the global economy.In order to revive Europe, it is necessary to strengthen human capital and employability by upgrading skills. However, for training at the skills is not enough: it is equally important to ensure a better match between skills supply and labor market demand compliance. Skills are very important for the recovery of the short and long-term growth and productivity, for its jobs and its capacity to adapt to changes in justice, gender equality and social cohesion. However, having a job and are able to work is essential and motivation. Motivation is a tool for achieving organizational goals.

The literature distinguishes two motivation measures were material and immaterial means of motivation. Studies show that the material measures are effective means of organizational goals. Kumpikaite, Kalinauskiene (2011) state that motivation is very popular and often is on the topic of the scientific literature Motivation researchers were interested in the problem ever since the ancient times. There are written many scientific papers on the subject at issue of motivation causes and origins, distinguished form of motivation, and types and so on. In the global economy, the country's governance, enterprise business organization, it is of great importance to properly motivate the people who carry out one or the other activity. So far, the motivation to human reason was the very large issue, but its application in practice - rather weak. Correctly motivated organization, an organization will enhance operational efficiency, but it is not fully understood Lithuania corporate executives and employees do not always want both tangible and intangible reasons.

Motivation purpose is to encourage workers. It took place at all times, even if it was not named as a motivation or encouragement. In earlier times, the role of motivation by fear prevailed. Nowadays it is necessary to understand the reasoning; it's a big range of people's needs, which needed to be met in order achieve satisfaction in job place. Therefore, the manager seeking to maximize results and rational that 
without dedicated employees for their work, it is not possible to achieve this it is essential to be able to recognize the needs of the people and try to get them to be satisfied with the work process (Čerbatik 2010). Familiarity with the needs of employees is a complex process, which is the company's directors are very demanding, but quite effective way. Marcinkevičiūtè, Petrauskienè (2009) argues that literature can meet the various theories of motivation classifications which refer to employee performance and the reasons for their choices.

Most motivation theories developed in the U.S. and apply to Americans. The most obvious characteristic of these theories of the American feature is that the strong emphasis on individualism and quality of life factors. Common among these theories is that the most important role of the person's knowledge, to choose what is important to him and the circumstances under which he works. Employees in every organization have material and immaterial motivation. Sometimes employees value more immaterial measures, such as career opportunities, training and good relationship with the manager, teamwork. However, material means of motivation, such as wages, bonuses, and so on can not be neglected. Musulaitė, Labžentienè (2008) states that according to the wishes of staff knowledge and timely satisfaction of atsklisti helps and exploiting every organization the staff competence, creativity, imagination, experience and expertise.

Motivation theory helps to understand the dynamic relations in the world, in which the organization operates, show relationships between superiors and subordinates in the organization. Palidauskaité, Segalovičienè (2008) argues that employee motivation is the subject of the age of both psychology and management and the sociology of organizations, as well as other fields of science theorists and practitioners' attention. This problem is dealt with management theorists such as Marcinkevičiūtė (2003, 2005, 2006), Sakalas (2001, 2003), Pritchard and Ashwood (2008) and others dealt with employee motivation and reasoning problems. Most of the studies that led to the theory of motivation have been carried out in the private sector. We are well aware that a majority of private sector organizations pursuit profit, and public sector institutions aim to meet consumer needs and expectations. Maslow's theory of motivation (1943) classified the human needs into five hierarchical levels of the pyramid. They would include:

- Physiological needs (hunger, thirst, sleep and so on.);

- Security needs (physical and social security);

- Social needs (the need for love, demand);

- Respect and esteem needs (success, recognition, evaluation, approval requirements);

- Expression needs (personal development, creativity, performance actualization of individuality needs).

According to Žaptorius (2007) motivation theory helps to understand the content of a dynamic relationship world in which organization, describing the daily management and employee communications organizations. Early theories of motivation are:

- The traditional model of managers defines the most effective methods of performing the task, and then encourages staff salary system. This model can not be applied for a long time, because the material to motivate employees by the employer can not for a long time.

- People relationship model number of tasks tedium and repetition reduces motivation, while so played by social contact helps to build motivation and strengthen it. Here it is important to maintain a good relationship with the staff. Motivate them to praise and honor letters.

- Human resources model subordinates may manipulated, then the simplified motivational significance and focuses on the monetary and social relations. Various means in order to maintain good workplace specialists are cherished employee performance in their job satisfaction.

\section{Research data analysis}

The research was conducted V.A.Graičiūnas high management school in 2013 of January. The study involved 108 students. 37 percent respondents were male and 63 percent respondents were female. 39 percent respondents were 18-20 years of age, 61 percent. - 21-24 m. age. The sample was calculated when the population size is known. Sample size was set according to the formula:

$$
n=\frac{N \cdot 1.96^{2} \cdot p \cdot q}{\varepsilon^{2} \cdot(N-1)+1,96^{2} \cdot p \cdot q}
$$


where $\mathrm{N}$ - size of the population; value of 1.96 meets the standardized normal distribution 95 percent level of confidence; $\mathrm{p}$ is a planned event probability that the feature will occur in the target population (most likely taken the worst option - a feature typical half, or 50 percent. populations, and choose $\mathrm{p}=0.5$ ); $\mathrm{q}$ is the probability that the symptom to occur in the target population $(\mathrm{q}=1-\mathrm{p}=0.5)$; $\varepsilon$ is the desired accuracy, usually $\varepsilon=0.05$

The respondents were asked the question "Have you ever heard of employee motivation tools?" 67 percent respondents have heard and spoken as well and 33 percent respondents were not - not heard. Respondents were asked to rate the importance of Maslow's needs. Respondents' opinion of the average is presented in Table 1. As can be seen from Table 1, best most respondents evaluate the physiological needs, the second the security needs of the third place - the respect and esteem needs, the fourth - the needs of self-expression, in fifth place social needs.

Table 1. Respondents' views on the importance of Maslow's

\begin{tabular}{|l|l|}
\hline The importance of Maslow's hierarchy of needs & Point average \\
\hline Physiological needs (hunger, thirst, sleep and so on.) & 3,8 \\
\hline $\begin{array}{l}\text { Security needs (physical and social security - to protect against the pain, the fear, the right to } \\
\text { education, work, retirement) }\end{array}$ & 3,7 \\
\hline Social needs (the need for love, the need for belonging to a group) & 2,3 \\
\hline Respect and esteem needs (success, recognition, evaluation, approval needs) & 2,7 \\
\hline $\begin{array}{l}\text { Expression needs (personal development, creativity, performance actualization of individuality } \\
\text { needs) }\end{array}$ & 2,6 \\
\hline
\end{tabular}

Source: developed by author

Respondents were asked to rank motivating factors by relevance. Respondents' opinion is presented in Table 2.

Table 2. Motivation factors

\begin{tabular}{|l|l|l|l|l|l|l|l|l|l|l|l|l|}
\hline Motivation factors & $\mathbf{1}$ & $\mathbf{2}$ & $\mathbf{3}$ & $\mathbf{4}$ & $\mathbf{5}$ & $\mathbf{6}$ & $\mathbf{7}$ & $\mathbf{8}$ & $\mathbf{9}$ & $\mathbf{1 0}$ & $\mathbf{1 1}$ & $\mathbf{1 2}$ \\
\hline desire to excel & & 18 & & & & 10 & 26 & & 8 & 19 & 1 & 9 \\
\hline interesting work & & 17 & 10 & & 9 & 18 & & 17 & 17 & 11 & & 9 \\
\hline good relationships with managers and colleagues & & & 9 & 18 & 9 & & 8 & 19 & 18 & 9 & 18 & \\
\hline Satisfaction & 10 & & 10 & 16 & 9 & 9 & 9 & 18 & 9 & 18 & & \\
& & & & & & & & & & & \\
\hline Salary & 20 & & 8 & & & 17 & 9 & 9 & 9 & 9 & 17 & 10 \\
\hline the importance of the work & 9 & 18 & 9 & & 18 & 9 & 18 & 9 & 9 & & 9 & \\
\hline periodically rising wages & & 10 & & 26 & 17 & 10 & 18 & & 9 & 9 & & 9 \\
& & & & & & & & & & & \\
\hline social security & & & & & & & & & & \\
\hline working conditions & 20 & 16 & 9 & 9 & & 9 & & 18 & 9 & 9 & 9 & \\
\hline workplace safety & & 8 & 8 & & 8 & 15 & 18 & & 9 & 9 & 18 & 9 \\
\hline Leave & & 18 & 9 & 18 & 9 & & & & & 18 & 9 & 9 \\
\hline career advancement & 36 & & 18 & 18 & 9 & & & & & & 9 & 18 \\
\hline
\end{tabular}

Source: developed by author

The respondents were asked the question "What do you value most at work?" 47 percent respondents said that they appreciate the opportunity to use their abilities, 87 percent - a good salary, 38 percent - an opportunity to improve their professional-level qualification. At least 10 percent of the respondents value the ability to be self-employed and 17 percent - creativity. The study showed that the vast majority of the respondents are mostly due to the good salary and the opportunity to use their abilities.

Hence, respondents value the most a good salary (Table 3). The respondents were asked the question "what skills are needed most managers?" 67 percent respondents believe that the ability to provide perspective, 46 percent - the ability to control the work of others, 35 percent - the ability to adjust the production process. 
Table 3. Respondents answer to the question "What do you value most at work?" (Choose three answers) opinion distribution

\begin{tabular}{|l|l|}
\hline Value tools at work & Percent \\
\hline Creativity & 17 \\
\hline The ability to use your abilities & 47 \\
\hline The ability to lead positions & 35 \\
\hline Work friends recognition & - \\
\hline The ability to upgrade their professional qualification-level & 38 \\
\hline The ability to be independent & 10 \\
\hline Good salary & 87 \\
\hline The friendly staff & - \\
\hline Other & - \\
\hline
\end{tabular}

Source: developed by author

The results showed that most managers need the ability to provide perspective. Thus, the manager must have the ability to plan strategically. It is also a very important time of the respondent's ability to control the work of others (Table 4).

Table 4. Abilities most needed for managers

\begin{tabular}{|l|l|}
\hline Abilities most needed for managers & Percent \\
\hline The ability to provide perspective & 67 \\
\hline Being able to use the employee reserve & 17 \\
\hline The ability to regulate the production process & 35 \\
\hline Ability to innovate & 17 \\
\hline Ability to delegate tasks & 33 \\
\hline The ability to control others work & 46 \\
\hline Being able to complete the work on time & 17 \\
\hline Being able to properly promote and punish & - \\
\hline Ability to train others to work & - \\
\hline Other & - \\
\hline
\end{tabular}

Source: developed by author

Respondents were asked to rate the material motivation measures. Respondents' opinions are presented in Table 5.

Table 5. Respondents' views on the tangible motivation measures

\begin{tabular}{|c|c|c|c|c|c|}
\hline \multirow[t]{2}{*}{ Tangible measures } & 5 & 4 & 3 & 2 & 1 \\
\hline & frequency & Frequency & frequency & frequency & frequency \\
\hline Reward & 90 & & 9 & & 9 \\
\hline Addition to salary & 45 & 36 & 18 & & 9 \\
\hline 3. Fixed bonuses for a job well done & 45 & 36 & 9 & 9 & 9 \\
\hline 4. Accessories for the achievement of collective results & 9 & 27 & 40 & 9 & 9 \\
\hline 5. The premium for these years & 40 & 18 & 18 & 18 & 9 \\
\hline 6. Gifts - Certificates (eg, shopping for any given store) & 40 & 18 & 18 & 9 & 18 \\
\hline 7. Purchase of tickets to the sports club, theater, concerts and so on. & 9 & 18 & 18 & 40 & 18 \\
\hline 8. Given access to the organization's machine & 9 & 40 & 9 & 9 & 9 \\
\hline 9. Reimbursement of transport costs & 45 & & 45 & 9 & 9 \\
\hline $\begin{array}{l}\text { 10. Discounts buying company's products (phones, phone accessories and } \\
\text { accessories) }\end{array}$ & 40 & 18 & 18 & 18 & 9 \\
\hline 11. Insurance against accidents at work & 54 & 36 & & 9 & 9 \\
\hline 12. Sending internships and seminars (eg, sales, customer quality) & 36 & 27 & 18 & 9 & 18 \\
\hline 13. Payments to pension funds & 18 & 63 & 18 & & 9 \\
\hline 14. Informal organizations holidays (eg, summer and winter holidays) & 27 & 36 & 18 & & \\
\hline 15. Specialized clothing & 18 & 36 & 36 & 9 & 9 \\
\hline 16. Personal phone calls and bills for payment & 54 & 36 & & 18 & \\
\hline 17. Holiday gifts (eg, St.. Occasion of Christmas) & 40 & 9 & 54 & & 9 \\
\hline 18. Miscellaneous allowances (birth, funerals, birthday occasion and so on.) & 54 & 27 & 9 & 18 & 9 \\
\hline
\end{tabular}

Source: developed by author 
As can be seen from the table, most respondents pay attention to the monetary reward, a salary bonus, fixed bonuses for a job well done, insurance against accidents at work, the working phone and the various benefits. Fewer respondents enhancements for the achievement of collective results, purchase of tickets to the sports club, theatre, concerts and so on, given access to the organization's machine. It can therefore be concluded that the respondents most motivated monetary reward.

Respondents were asked to rate the importance of the aspects of the work. Respondents' opinions are presented in Table 6. As seen respondents strongly influenced by employee training (courses, seminars, lectures, etc.)., Company culture and employee philosophy, increase employee satisfaction, compatibility, flexible working time, promotion, permanent staff assessment, the relationship between pay and performance. The respondents were asked the question, "What is job for you?" 65 percent respondents said that work - only source of income, 65 percent - source of income and the opportunity to realize their abilities and experience, 37 percent - source of income and satisfaction with participation in common activities.

Table 6. Working importance

\begin{tabular}{|l|l|l|l|l|l|}
\hline \multirow{2}{*}{ Working importance } & 5 & 4 & 3 & 2 & 1 \\
\cline { 2 - 6 } & Frequency & frequency & Frequency & frequency & Frequency \\
\hline Specialized tasks appointment & 18 & 9 & 63 & 18 & 9 \\
\hline Job skills & 45 & 45 & 9 & 9 & - \\
\hline Accurate job adjustment & 54 & 45 & 9 & 9 & - \\
\hline Autonomy and responsibility & 54 & 45 & 9 & 9 & - \\
\hline $\begin{array}{l}\text { Additional delegation of authority and } \\
\text { responsibility }\end{array}$ & 27 & 54 & 27 & 9 & - \\
\hline $\begin{array}{l}\text { Employee training (courses, seminars, lectures, } \\
\text { etc.) }\end{array}$ & 63 & 36 & 18 & - & - \\
\hline $\begin{array}{l}\text { Corporate culture and employee philosophy } \\
\text { compatibility }\end{array}$ & 63 & 36 & 18 & - & \\
\hline Employee self-satisfaction increase & 72 & 36 & - & - \\
\hline Open the employer and employee communications & 36 & 72 & - & - & - \\
\hline $\begin{array}{l}\text { Additional incentives (health insurance, travel } \\
\text { insurance, pension, etc.) }\end{array}$ & 54 & 36 & 18 & - & - \\
\hline Bonuses & 54 & 36 & 18 & - & 9 \\
\hline Thanksgiving and praise orally and writing & 54 & 36 & 18 & - & 9 \\
\hline Flexible working time & 63 & 36 & - & - & - \\
\hline Promotion & 63 & 36 & - & - & - \\
\hline Continuous assessment of staff & 63 & 36 & - & - & - \\
\hline The link between pay and performance & 63 & 36 & - & - & - \\
\hline
\end{tabular}

Source: developed by author

The results showed that the vast majority of respondents treat teir work as a source of income and the opportunity to realize their abilities and gain experience.

\section{Conclusions}

Employee motivation is realized depending on the organization and the needs of employees and the necessity, influenced by the environment. This requires the environmental and organizational needs analysis and, especially important to find out the individual needs of employees because in order to motivate people to be aware of their properties, which in turn leads to their needs. The material motivation tools include wages, in addition to salary, bonuses, gifts, purchase of tickets to the sports club, theatre, concerts, the car discounts when buying organization products, insurance, office phone, festive gifts etc.

The results showed that respondents are most appreciated by the physiological needs, the second - the security requirements of the third place - the respect and esteem needs, the fourth - the needs of selfexpression, in fifth place -social needs. In terms of importance of motivating factors, focusing on respondents gave wages and social security, vacation time. 
Majority of respondents expect at their work to use their abilities, to receive a good salary, and to get an opportunity to enhance their professional qualification. At least the respondents used the opportunity to be independent and creative.

Most respondents appreciate monetary reward, a salary bonus, fixed bonuses for a job well done, insurance against accidents at work, the working phone and the various benefits. Fewer respondents' are interested in collective results, purchase of tickets to the sports club, theatre, concerts and so on.

Respondents are strongly influenced by employee training (courses, seminars, lectures, etc.). By forming appropriate company culture and employee philosophy, you increase employee satisfaction via compatibility, flexible working time, promotion, ongoing staff evaluation, the relationship between pay and performance.

\section{References}

Atkinson, J.; Feather, N. 1974. A Theory of Achievement Motivation (6 ed.). Krieger Pub Co.

Atkinson, J.; Raynor, O. 1978. Personality, Motivation and Achievement. Hemisphere Pub. Corp.

Atkinson, J.; George H. Litwin. 1960. Achievement Motive and Text Anxiety Conceived as Motive to Approach Success and Motive to Avoid Failure. Bobbs-Merrill Company.

Čerbatik J.V. 2010. Psichology of organization and business. Available on the Internet: <http://www.nostress.ru/buisness/motivation.html>.

Education Development Center 2012. Employment skills and working knowledge of the world of methodical recommendations. Published in Education Development Center.

Greenberg, J.; Baron, A.R. 2003. Behaviour in organisations. Prentice Hall.

Helepota, H.A. 2005. Motivational theories and their application in construction, Cost engineering 47(3): 196-204.

Kim, S. 2005. Individual Level Factors and Organizational Performance in Government Organizations, Journal of Public Administration Research and Theory 15(2): 245-261.

Kumpikaitè, V.; Kalinauskienè, J. 2011. Motivation needs and identification of social status: a theoretical analysis. Kaunas: Technology.

Marcinkevičiūtè, L.; Petrauskienė, R. 2009. Municipal social workers the practical aspects of motivation, Public Policy and Administration 27: 63-68.

Marcinkevičiūtè, L. 2003. Lithuanian company employee motivation model features a changing market conditions. Doctoral dissertation.

Marcinkevičiūtè, L. 2005. Municipal employee motivation theoretical and practical aspects, Economics and Management: current issues and perspectives: 5: 239-247.

Marcinkevičiūtè, L. 2006. Employee motivation models, Bridges 1: 11-18.

Maslow, A.H. 1943. A Theory of Human Motivation, Psychological Review 50(4): 370-396.

Musulaite, R.; Labžentienè, M. 2008. Teacher motivation characteristics of colleges, Economics and Management: current issues and perspectives 3(12): 189-198.

Palidauskaite J.; Segalovičienè I. 2008. Motivation of civil servants Lithuania Profile: empirical analysis of the results, Management of Organizations: Systematic Research 47: 74-90.

Pritchard, R.; Ashwood, E. 2008. Managing Motivation. New York: Taylor \& Francis Group.

Sakalas, A. 2001. Personnel Management. Kaunas: Technology.

Sakalas, A. 2003. Personnel Management. Vilnius: Various widgets.

Žaptorius, J. 2007. Employee motivation system design and theoretical analysis, Philosophy. Sociology 4: 105-117. 
Dr. Margarita Išoraite holds position of as an associated professor at Vilnius College. Research interests: marketing, strategic marketing, advertising, branding, human resource. 